\title{
PERLAKUAN AKUNTANSI PENDAPATAN DAN BEBAN BERBASIS SAK ETAP DAN IMPLIKASINYA PADA LAPORAN KEUANGAN KOPERASI KARYAWAN KARYA SAMPURNA PT. BANK MANDIRI
}

\author{
Anggelina Chrisdayanti Salindeho ${ }^{1}$, Lintje Kalangi ${ }^{2}$ Sonny Pangerapan ${ }^{3}$ \\ ${ }^{1,2,3}$ Jurusan Akuntansi, Fakultas Ekonomi dan Bisnis, Universitas Sam Ratulangi, Jl. Kampus Bahu, Manado, \\ 95115, Indonesia \\ E-mail : kimshfly11@gmail.com
}

\begin{abstract}
Cooperative is an association established by persons or legal entities of cooperatives that have limited economic ability, with the aim to improve the welfare of its members. Revenues and expenses are an important component of financial statements because different treatment of income and expenses will result in changes in the resulting financial statements. Financial Accounting Standards intended for cooperative entities are SAK ETAP. This study aims to determine the accounting treatment of income and expenses on Cooperative Employees Karya Sampurna PT. Bank Mandiri in accordance with SAK ETAP. The research method used in this thesis research is descriptive method whose purpose each data collected in the analysis and then drawn a conclusion and the type of research used is qualitative descriptive. The results obtained that the accounting treatment of income and expenses on Cooperative Employees Karya Sampurna PT. Bank Mandiri is in compliance with SAK ETAP.
\end{abstract}

Keywords: Accounting treatment, income, expenses.

\section{PENDAHULUAN}

Usaha Mikro Kecil dan Menengah mempunyai peran yang sangat penting dalam perekonomian Indonesia. Dilihat dari sisi perkembangannya Usaha Mikro Kecil Menengah menjadi suatu sarana aktivitas ekonomi bagi masyarakat dalam menyediakan sumber penghasilan, tenaga kerja dan juga merupakan suatu bentuk pola pemikiran yang kreatif di zaman globalisasi ini. Dalam perkembangannya di Indonesia, Usaha Mikro Kecil Menengah (UMKM) sudah sangat berkembang, dan sangat banyak jenis usahanya.

Koperasi merupakan bagian dari UMKM, yang memerlukan pencatatan akuntansi dalam menunjang usahanya. Berkaitan dengan penyusunan laporan keuangan pada suatu entitas, PSAK No.27 tentang akuntansi perkoperasian tidak berlaku lagi. Pada Standar Akuntansi Keuangan yang diterbitkan bulan Juni 2012, PSAK No.27 tidak tercantum. Disamping itu sesuai dengan surat edaran Deputi Kelembagaan Koperasi dan UMKM RI Nomor: 200/SE/Dept.1/XII/2011 tanggal 20 Desember bahwa sehubungan pemberlakuan IFRS, maka entitas Koperasi dalam penyusunan dan penyajian laporan keuangannya mengacu pada Standar Akuntansi Keuangan Entitas Tanpa Akuntabilitas Publik (SAK ETAP).

SAK ETAP dalam pedoman penyusunan laporan keuangan dibuat lebih sederhana. SAK ETAP terpisah dari SAK besar dimana SAK ETAP dalam pedoman penyusunan laporan keuangan dibuat lebih sederhana. Latar belakang disusunnya SAK ETAP yang terpisah dari PSAK adalah karena PSAK (Pernyataan Standar Akuntansi Keuangan) yang mengadopsi International Financial Reporting Standard (IFRS) terlalu kompleks jika diterapkan oleh usaha kecil di Indonesia. Maka dari itu diperlukan standar yang lebih sederhana dan memudahkan usaha kecil dalam penyusunan laporan keuangan. Umumnya, entitas tanpa akuntabilitas publik adalah perusahaan mikro, kecil dan menengah (UMKM), 
koperasi, Bank Perkreditan Rakyat (BPR) sehingga pengguna ETAP akan banyak terdiri dari entitas dengan kategori UMKM.

Koperasi Karyawan Karya Sampurna PT. Bank Mandiri memiliki badan hukum No. 2446/BH/V, yang bergerak dalam unit usaha simpan pinjam, waserda, travel dan fotocopy. Koperasi ini berdiri sejak tanggal 1 April 1989 dan memiliki anggota sebanyak 264 orang hingga saat ini. Kesehatan usaha dan kejujuran dalam pelaporan keuangan sangat dijunjung oleh Koperasi Karyawan Karya Sampurna PT. Bank Mandiri, karena koperasi ini menganggap kepercayaan anggota sangat determinan dalam mendukung perkembangan koperasi. Namun koperasi ini hanya menyusun 2 jenis laporan keuangan saja, yaitu neraca dan laba rugi. Dimana belum sesuai dengan standar akuntansi yang berlaku untuk koperasi yaitu SAK ETAP.

Masalah utama pendapatan yaitu bagaimana menentukan saat pengakuan pendapatan, jika penerapan sesuai transaksi serta sesuai Standar Akuntansi Keuangan yang berlaku maka pendapatan yang diterapkan dapat dikatakan wajar. Selain pendapatan, beban juga merupakan faktor yang mempengaruhi kewajaran laporan keuangan dan diakui dalam laporan Laba Rugi berkaitan dengan penurunan aset dan diukur dengan handal. Pemilihan metode maupun teknik dalam akuntansi dapat berpengaruh terhadap pengakuan pendapatan dan beban. Dalam pelaporan keuangan yang menjadi pusat perhatian dalam laporan laba rugi adalah total pendapatan, beban dan laba.

\section{TINJAUAN PUSTAKA}

\subsection{Akuntansi}

Menurut Kieso D. E, Weygandt J. J dan Warfield T. D (2016:2) akuntansi terdiri dari tiga kegiatan yang mendasar yaitu identifikasi, pencatatan dan pengkomunikasian peristiwa ekonomi suatu organisasi kepada pihak yang berkepentingan. Perusahaan mengidentifikasi peristiwa ekonomi sesuai dengan kegiatan usahanya dan mencatat peristiwa tersebut untuk menyediakan catatan kegiatan keuangan. Pencatatan dilaksanakan secara sistematis, kronologis setiap peristiwa, dalam satuan mata uang. Akhirnya pada pengkomunikasian kumpulan informasi tersebut kepada pihak yang berkepentingan dalam bentuk laporan akuntansi atau dikenal dengan laporan keuangan.

\subsection{Pendapatan}

Menurut Reeve, Jusuf Warren dan Duchar. K (2013:18) pendapatan diartikan sejumlah uang yang diterima perusahaan dengan menjual barang atau jasa. Pendapatan berhubungan dengan penghasilan yang diterima perusahaan, timbul karena adanya penjualan. Pendapatan juga sangat penting untuk berjalannya suatu perusahaan karena untuk membiayai segala pengeluaran dan aktivitas perusahaan, dan tidak semua kenaikan dalam asset bisa dikatakan sebagai pendapatan.

\subsubsection{Sumber dan Jenis Pendapatan}

Sumber dan jenis pendapatan ini merupakan suatu unsur yang perlu mendapat perhatian penting sebelum membahas masalah pengakuan dan pengukuran pendapatan lebih lanjut.

Secara garis besar pendapatan digolongkan menjadi tiga golongan (Suparmoko dalam Artaman, 2015), yaitu :

1. Gaji dan upah.

2. Pendapatan dari usaha sendiri.

3. Pendapatan dari usaha lain.

\subsubsection{Pengakuan Pendapatan}

Menurut Suwardjono (2013) pengakuan pendapatan merupakan proses pencatatan seluruh jumlah pendapatan kedalam sistem akuntansi sehingga jumlah tersebut tergambarkan dalam statemen keuangan. Berdasarkan waktu dan jenis usahanya, pengakuan pendapatan 
tidak dapat disamakan satu sama lain. Perusahaan yang bergerak di bidang yang berbeda akan mempunyai cara yang berbeda dalam pengakuan dan pencatatan pendapatannya. Pengakuan pendapatan tidak selalu dilakukan saat penjualan telah terjadi.

\subsection{Beban}

Beban didefinisikan sebagai pengurangan masa pemakaian suatu aktiva selama suatu periode akuntansi dalam perusahaan. Menurut Reeve, Jusuf Warren dan Duchar. K (2013:19) beban diartikan sebagai uang yang digunakan dalam proses memperoleh pendapatan.

\subsubsection{Pengakuan Beban}

Umumnya beban diakui pada saat terjadinya penurunan nilai atau tidak ada lagi manfaat dimasa yang akan datang. Beban juga dapat diakui pada saat terjadinya pengeluaran kas, apabila perusahaan menggunakan metode kas atau cash basis.

Ada beberapa metode pengakuan beban yaitu sebagai berikut :

1. Penandingan langsung (Direct Matching)

2. Pengakuan segera (Immediate Recognition)

3. Alokasi yang sistematik dan rasional.

\subsection{Standar Akuntansi Keuangan Entitas Tanpa Akuntabilitas Publik}

Standar Akuntansi Keuangan Entitas Tanpa Akuntabilitas Publik atau SAK ETAP merupakan standar akuntansi keuangan yang diperuntukkan bagi entitas tanpa akuntabilitas publik. SAK ETAP disahkan oleh 18 orang anggota Dewan Standar Akuntansi Keuangan pada tanggal 19 Mei 2009 di Jakarta. SAK ETAP merupakan standar akuntansi keuangan yang dirancang untuk memudahkan perusahaan kecil seperti UMKM dalam membuat laporan keuangan. Karena ruang lingkupnya, membuat SAK ETAP sebagai standar akuntansi keuangan yang cocok digunakan oleh entitas tanpa akuntabilitas publik.

\subsubsection{Perlakuan Akuntansi Standar Akuntansi Keuangan Entitas Tanpa Akuntabilitas Publik}

Pura (2013:25) perlakuan akuntansi adalah bagaimana suatu transaksi atau kejadian tersebut diperlakukan di dalam akuntansi. Untuk memperlakukan kejadian tersebut, ada beberapa konsep yang terkait dengan perlakuan akuntansi yaitu dengan konsep pengakuan, pengukuran, pencatatan, penyajian, dan pengungkapan.

\subsection{Laporan Keuangan}

Laporan keuangan adalah hasil akhir dari proses akuntansi sebuah perusahaan yang memberikan informasi keuangan bagi pihak internal maupun eksternal perusahaan. Kieso D. E, Weygandt J. J dan Warfield T. D (2016) analisis laporan keuangan melibatkan evaluasi terhadap tiga karakteristik yaitu likuiditas, profitabilitas, dan solvabilitas perusahaan.

\subsection{Penelitian Terdahulu}

Penelitian terdahulu yang penulis jadikan sebagai bahan pertimbangan dalam melakukan penelitian di Karyawan Karya Sampurna PT. Bank Mandiri. Penelitian yang dilakukan oleh Rini, Zulkarnain, dan Widodo tahun 2014, tentang Analisis Pengakuan Pendapatan dan Beban serta Pengaruhnya Terhadap Kewajaran Penyajian Laporan Keuangan Pada PT Mitra Andalan Satkomindo menyatakan bahwa PT Mitra Andalan Satkomindo selama ini menerapkan metode cash basis dalam pengakuan pendapatan dan beban yang belum sesuai dengan Standar Akuntansi Keuangan dan terdapat ketidaksesuaian dalam penyajian laporan keuangan karena perusahaan hanya menyajikan laporan laba rugi saja.

\section{METODE PENELITIAN}

\subsection{Jenis Penelitian}

Penelitian yang dilakukan merupakan penelitian deskriptif. Penelitian deskriptif merupakan penelitian yang menjelaskan setiap data yang diperoleh, fenomena yang terjadi dan hasil penelitian di lapangan yang ditemukan, dalam bentuk kata-kata yang menceritakan, 
mengemukakan dan menggambarkan situasi tersebut yang memiliki makna sesuai dengan hasil penelitian yang dilakukan.

\subsection{Waktu dan Tempat Penelitian}

Penelitian ini dilaksanakan pada Koperasi Karyawan Karya Sampurna PT. Bank Mandiri yang bertempat di Jalan Dotulolong Lasut Nomor 15- 19 Manado. Waktu penelitian dimulai dari bulan Maret sampai dengan bulan April 2018.

\subsection{Prosedur Penelitian}

Mengidentifikasi masalah, menentukan objek penelitian, penyusunan proposal penelitian, pengumpulan data, menganalisis dan mengolah data, hasil penelitian, membuat kesimpulan dan memberikan saran

\subsection{Metode Analisis}

Metode penelitian yang digunakan dalam penelitian ini adalah metode deskriptif. Metode penelitian deskriptif adalah metode yang digunakan untuk mendeskripsikan dan menginterpretasikan suatu fenomena, misalnya kondisi atau hubungan yang ada, pendapat yang berkembang, dengan menggunakan prosedur ilmiah untuk menjawab masalah secara aktual.

\section{HASIL ANALISIS DAN PEMBAHASAN}

4.1 Hasil analisis

4.1.1 Perlakuan Akuntansi atas Pendapatan pada Koperasi Karyawan Karya Sampurna PT. Bank Mandiri

Adapun perlakuan akuntansi pendapatan pada Koperasi Karyawan Karya Sampurna

PT. Bank Mandiri adalah sebagai berikut:

1. Perlakuan Pendapatan Pinjaman Uang Kepada Anggota dan Non Anggota

a. Pengakuan

Pengakuan pendapatan atas pinjaman uang kepada anggota dan non anggota pada Koperasi Karyawan Karya Sampurna PT. Bank Mandiri diakui menggunakan metode accrual basis, dimana koperasi mempunyai hak untuk melakukan penagihan dari hasil kegiatan tersebut.

b. Pengukuran

Pengukuran pendapatan atas pinjaman uang kepada anggota dan non anggota pada Koperasi Karyawan Karya Sampurna PT. Bank Mandiri diukur dengan nilai wajar atas pembayaran dari pihak yang melakukan pinjaman.

c. Penyajian

Penyajian pendapatan atas pinjaman uang kepada anggota dan non anggota pada Koperasi Karyawan Karya Sampurna PT. Bank Mandiri disajikan dalam Laporan Keuangan Laba Rugi.

d. Pengungkapan

Di samping disajikan dalam Laporan Laba Rugi pendapatan atas pinjaman uang dan pendapatan atas barang pada Koperasi Karyawan Karya Sampurna PT. Bank Mandiri harus diungkapkan sedemikian rupa pada Catatan atas Laporan Keuangan.

2. Perlakuan Pendapatan Penjualan Barang Konsumsi

a. Pengakuan

Pengakuan pendapatan atas penjualan barang konsumsi pada Koperasi Karyawan Karya Sampurna PT. Bank Mandiri diakui menggunakan metode accrual basis, yaitu pada saat koperasi menerima pembayaran secara tunai dari pembeli.

b. Pengukuran

Pengukuran pendapatan penjualan barang konsumsi di Koperasi Karyawan Karya Sampurna PT. Bank Mandiri diukur sesuai dengan nilai wajar atas transaksi pembelian.

c. Penyajian 
Penyajian pendapatan penjualan barang konsumsi pada Koperasi Karyawan Karya Sampurna PT. Bank Mandiri disajikan dalam Laporan Keuangan Laba Rugi.

d. Pengungkapan

Di samping disajikan dalam Laporan Laba Rugi pendapatan atas penjualan barang konsumsi pada Koperasi Karyawan Karya Sampurna PT. Bank Mandiri harus diungkapkan sedemikian rupa pada Catatan atas Laporan Keuangan.

3. Perlakuan Pendapatan Bunga Tabungan Mandiri

a. Pengakuan

Pengakuan pendapatan atas Bunga Tabungan Mandiri pada Koperasi Karyawan Karya Sampurna PT. Bank Mandiri diakui menggunakan metode acrual basis, yaitu sesuai dengan bunga Bank Mandiri yang ditentukan

b. Pengukuran

Pengukuran pendapatan Bunga Tabungan Mandiri di Koperasi Karyawan Karya Sampurna PT. Bank Mandiri diukur sesuai dengan nilai wajar yang sudah ditentukan Bank Mandiri.

c. Penyajian pendapatan atas Bunga Tabungan Mandiri pada Koperasi Karyawan Karya Sampurna PT. Bank Mandiri disajikan dalam Laporan Keuangan Laba Rugi

d. Pengungkapan

Di samping disajikan dalam Laporan Laba Rugi pendapatan atas Bunga Tabungan Mandiri pada Koperasi Karyawan Karya Sampurna PT. Bank Mandiri harus diungkapkan sedemikian rupa pada Catatan atas Laporan Keuangan.

4. Pendapatan Lain-lain

Pendapatan lain-lain dibagi menjadi 3, yaitu:

1) Pendapatan Administrasi

2) Pendapatan Cleaning Service

3) Pendapatan Benda-Benda Pos

4) Pendapatan Jasa Kebersihan ATM

a. Pengakuan

Pengakuan pendapatan atas administrasi, cleaning service, benda-benda pos, dan jasa kebersihan ATM pada Koperasi Karyawan Karya Sampurna PT. Bank Mandiri diakui menggunakan metode accrual basis, dimana koperasi mempunyai hak atas jasa-jasa yang diberikan.

b. Pengukuran

Pengukuran pendapatan atas administrasi, cleaning service, benda-benda pos, dan jasa kebersihan ATM pada Koperasi Karyawan Karya Sampurna PT. Bank Mandiri diukur dengan nilai wajar atas sesuai dengan jasa yang diberikan.

c. Penyajian

Penyajian pendapatan atas administrasi, cleaning service, benda-benda pos, dan jasa kebersihan ATM pada Koperasi Karyawan Karya Sampurna PT. Bank Mandiri disajikan dalam Laporan Keuangan Laba Rugi.

d. Pengungkapan

Di samping disajikan dalam Laporan Laba Rugi, pendapatan administrasi, cleaning service, benda-benda pos, dan jasa kebersihan ATM pada Koperasi Karyawan Karya Sampurna PT. Bank Mandiri harus diungkapkan sedemikian rupa pada Catatan atas Laporan Keuangan.

\subsubsection{Perlakuan Akuntansi atas Beban pada Koperasi Karyawan Karya Sampurna} PT. Bank Mandiri

Adapun perlakuan akuntansi atas beban pada pada Koperasi Karyawan Karya Sampurna PT. Bank Mandiri adalah sebagai berikut: 
a. Pengakuan

Pengakuan beban pada Koperasi Karyawan Karya Sampurna PT. Bank Mandiri diakui menggunakan metode acrual basis, yaitu diakui pada saat biaya yang dikeluarkan untuk membayar gaji yang ditetapkan Koperasi Karyawan Karya Sampurna PT. Bank Mandiri.

b. Pengukuran

Pengukuran beban pada Koperasi Karyawan Karya Sampurna PT. Bank Mandiri diukur dengan nilai wajar yang sesuai dengan nilai nominal yang dikeluarkan oleh koperasi tersebut.

c. Penyajian

Penyajian beban pada Koperasi Karyawan Karya Sampurna PT. Bank Mandiri disajikan dalam Laporan Keuangan Laba Rugi.

d. Pengungkapan

Di samping disajikan dalam Laporan Laba Rugi beban pada Koperasi Karyawan Karya Sampurna PT. Bank Mandiri harus diungkapkan sedemikian rupa pada Catatan atas Laporan Keuangan.

\subsection{Pembahasan}

\subsubsection{Analisis Perlakuan Akuntansi pada Koperasi Karyawan Karya Sampurna PT. Bank Mandiri}

Berdasarkan hasil penelitian yang dilakukan bahwa perlakuan akuntansi atas pendapatan pada Koperasi Karyawan Karya Sampurna PT. Bank Mandiri sebagian besar diakui berdasarkan metode acrual basis. Sedangkan, perlakuan akuntansi atas beban pada Koperasi Karyawan Karya Sampurna PT. Bank Mandiri diakui berdasarkan metode acrual basis.

Untuk perbandingan penyajian pendapatan dan beban pada laporan keuangan yang sesuai dengan SAK ETAP dapat dilihat pada Tabel 4.3

\begin{tabular}{|l|l|l|c|}
\hline No & \multicolumn{1}{|c|}{ Hasil Penelitian } & \multicolumn{1}{|c|}{ SAK ETAP } & Keterangan \\
\hline 1. & $\begin{array}{l}\text { Pendapatan dari anggota dan non } \\
\text { anggota dipisahkan. }\end{array}$ & $\begin{array}{l}\text { Pendapatan yang berasal dari } \\
\text { anggota dan non anggota harus } \\
\text { dipisahkan. }\end{array}$ & Sesuai \\
\hline 2. & $\begin{array}{l}\text { Tidak mengakui adanya partisipasi } \\
\text { bruto anggota. }\end{array}$ & $\begin{array}{l}\text { Pendapatan koperasi yang timbul } \\
\text { dari transaksi dengan anggota } \\
\text { diakui sebagai partisipasi bruto. }\end{array}$ & Belum Sesuai \\
\hline 3. & $\begin{array}{l}\text { Menggunakan istilah laporan laba } \\
\text { rugi. }\end{array}$ & $\begin{array}{l}\text { Menggunakan istilah laporan laba } \\
\text { rugi. }\end{array}$ & Sesuai \\
\hline 4. & $\begin{array}{l}\text { Dalam laporan laba rugi belum } \\
\text { memisahkan antara beban usaha } \\
\text { dan beban operasional. }\end{array}$ & $\begin{array}{l}\text { Beban harus disajikan } \\
\text { berdasarkan sifat atau fungsi } \\
\text { beban. }\end{array}$ & Belum Sesuai \\
\hline 5. & $\begin{array}{l}\text { Dalam laporan laba rugi mengakui } \\
\text { istilah biaya. }\end{array}$ & $\begin{array}{l}\text { Dalam SAK ETAP mengakui } \\
\text { istilah beban. }\end{array}$ & Belum Sesuai \\
\hline 6. & $\begin{array}{l}\text { Perhitungan Sisa Hasil Usaha } \\
\text { SHU) pada Koperasi Karyawan } \\
\text { Karya Sampurna adalah laporan } \\
\text { laba rugi dari koperasi ini. }\end{array}$ & $\begin{array}{l}\text { Laporan laba rugi koperasi } \\
\text { memiliki nama lain yaitu } \\
\text { Perhitungan Sisa Hasil Usaha } \\
\text { (SHU). }\end{array}$ & Sesuai \\
\hline 7. & $\begin{array}{l}\text { SHU dibagikan setiap akhir periode } \\
\text { sesuai dengan ketentuan yang } \\
\text { ditetapkan koperasi. }\end{array}$ & $\begin{array}{l}\text { Pembagian SHU harus dilakukan } \\
\text { pada akhir periode pembukuan. } \\
\text { Jumlah yang dibagi sesuai dengan } \\
\text { ketentuan koperasi. }\end{array}$ & Sesuai \\
\hline
\end{tabular}

Tabel 4.3 Perbandingan penyajian pendapatan dan beban pada laporan keuangan yang sesuai dengan SAK ETAP.

Dari tabel di atas, dapat dilihat bahwa untuk penyajian pendapatan dan beban dalam laporan keuangan Koperasi Karyawan Karya Sampurna ada beberapa peraturan yang belum sesuai dengan SAK ETAP. 


\subsubsection{Analisis Perlakuan Akuntansi Pendapatan pada Koperasi Karyawan Karya Sampurna PT. Bank Mandiri}

Adapun perlakuan pendapatan pada Koperasi Karyawan Karya Sampurna PT. Bank Mandiri dimana pengakuan pendapatan atas pinjaman uang kepada anggota dan non anggota, penjualan barang konsumsi, Bunga Bank Mandiri, cleaning service dan pendapatan lain-lain pada Koperasi Karyawan Karya Sampurna diakui menggunakan metode accrual basis. Pengukuran atas semua pendapatan pada Koperasi Karyawan Karya Sampurna PT. Bank Mandiri diukur dengan nilai wajar. Penyajiannya disajikan dalam Laporan Keuangan Laba Rugi.

Adapun pencatatan perlakuan akuntansi atas pendapatan pinjaman kepada anggota sebagai berikut:

\section{Tabel 4.4}

Koperasi Karyawan Karya Sampurna PT. Bank Mandiri Jurnal Pendapatan Pinjaman Kepada Anggota

\begin{tabular}{|c|c|c|}
\hline Nama Akun & Debet & Kredit \\
\hline Piutang & $\mathrm{xxx}$ & - \\
\hline Pendapatan pinjaman kepada anggota & - & $\mathrm{xxx}$ \\
\hline
\end{tabular}

Pada Tabel 4.3, menunjukkan bahwa piutang berada pada sisi debet, sedangkan pinjaman kepada anggota berada di sisi kredit.

Adapun jurnal untuk mencatat penjualan barang konsumsi sebagai berikut:

Tabel 4.5

Koperasi Karyawan Karya Sampurna PT. Bank Mandiri Jurnal Penjualan Barang Konsumsi

\begin{tabular}{|c|c|c|}
\hline Nama Akun & Debet & Kredit \\
\hline Kas & $\mathrm{xxx}$ & - \\
\hline Penjualan Barang Konsumsi & - & $\mathrm{xxx}$ \\
\hline
\end{tabular}

Pada Tabel 4.4, menunjukkan bahwa kas berada pada sisi debet, sedangkan penjualan barang konsumsi berada di sisi kredit.

Adapun jurnal untuk mencatat Bunga Bank Mandiri sebagai berikut:

Tabel 4.6

Koperasi Karyawan Karya Sampurna PT. Bank Mandiri

Jurnal Bunga Bank Mandiri

\begin{tabular}{|c|c|c|}
\hline Nama Akun & Debet & Kredit \\
\hline Bank & $\mathrm{xxx}$ & - \\
\hline Pendapatan Bunga Mandiri & - & $\mathrm{xxx}$ \\
\hline
\end{tabular}

Pada Tabel 4.5, menunjukkan bahwa Bank berada pada sisi debet, sedangkan pendapatan Bunga Mandiri berada di sisi kredit. 
Adapun jurnal untuk mencatat pendapatan cleaning service sebagai berikut:

Tabel 4.7

Koperasi Karyawan Karya Sampurna PT. Bank Mandiri

Jurnal Pendapatan Cleaning Service

\begin{tabular}{|c|c|c|}
\hline Nama Akun & Debet & Kredit \\
\hline Kas & $\mathrm{xxx}$ & - \\
\hline Pendapatan Cleaning Service & - & $\mathrm{xxx}$ \\
\hline
\end{tabular}

Pada Tabel 4.6, menunjukkan bahwa kas berada pada sisi debet, sedangkan pendapatan cleaning service berada di sisi kredit.

Adapun jurnal untuk mencatat pendapatan lain-lain sebagai berikut:

Tabel 4.8

Koperasi Karyawan Karya Sampurna PT. Bank Mandiri

Jurnal Pendapatan Lain-lain

\begin{tabular}{|c|c|c|}
\hline Nama Akun & Debet & Kredit \\
\hline Kas & $\mathrm{xxx}$ & - \\
\hline Pendapatan Lain-lain & - & $\mathrm{xxx}$ \\
\hline
\end{tabular}

Pada Tabel 4.7, menunjukkan bahwa kas berada pada sisi debet, sedangkan pendapatan lainlain berada di sisi kredit.

Setelah dilakukan pencatatan pada jurnal, pendapatan akan dimasukkan dalam laporan keuangan yaitu laba rugi kemudian akan dikurangi dengan beban-beban, sehingga menghasilkan sisa hasil usaha. Dimana sisa hasil usaha akan dibagikan kepada setiap anggota koperasi sesuai dengan besarnya transaksi anggota terhadap pembentukan pendapatan koperasi.

\subsubsection{Analisis Perlakuan Akuntansi Beban pada Koperasi Karyawan Karya} Sampurna PT. Bank Mandiri

Adapun perlakuan atas beban pada Koperasi Karyawan Karya Sampurna PT. Bank Mandiri dimana pengakuan Beban Gaji, Beban THR, Beban Honor Pengurus, Beban Gaji Cleaning Service, Beban lain-lain (Pajak PPh Pasal 21 Asuransi, ATM/Administrasi, Pemakaian/Perawatan, Alat-Alat Kantor Koperasi, dan Bunga PNM) diakui menggunakan metode accrual basis yaitu walaupun beban-beban tertentu telah terjadi, tetapi pembayarannya belum dilakukan, tetapi telah dicatat dan diakui sebagai beban atau biaya. Pengukuran atas semua beban pada Koperasi Karyawan Karya Sampurna PT. Bank Mandiri diukur dengan nilai wajar. Penyajiannya disajikan dalam Laporan Keuangan Laba Rugi.

Adapun pencatatan perlakuan akuntansi atas beban gaji yang terjadi namun belum dilakukan pembayaran oleh koperasi dicatat sebagai berikut:

\section{Tabel 4.9}

Koperasi Karyawan Karya Sampurna PT. Bank Mandiri Jurnal Beban Gaji

\begin{tabular}{|c|c|c|}
\hline Nama Akun & Debet & Kredit \\
\hline Beban Gaji & $\mathrm{xxx}$ & - \\
\hline Hutang Gaji & - & $\mathrm{xxx}$ \\
\hline
\end{tabular}

Pada Tabel 4.8, menunjukkan bahwa beban gaji berada pada sisi debet, sedangkan hutang gaji berada di sisi kredit. 
Adapun pencatatan perlakuan akuntansi atas beban gaji ketika pihak koperasi akan melakukan pembayaran atas beban yang ada maka koperasi akan mencatat sebagai berikut:

Tabel 4.10

Koperasi Karyawan Karya Sampurna PT. Bank Mandiri Jurnal Beban Gaji

\begin{tabular}{|c|c|c|}
\hline Nama Akun & Debet & Kredit \\
\hline Hutang Gaji & $\mathrm{XXX}$ & - \\
\hline Kas & - & $\mathrm{XXX}$ \\
\hline
\end{tabular}

Pada Tabel 4.10, menunjukkan bahwa hutang gaji berada pada sisi debet, sedangkan kas berada di sisi kredit.

Adapun pencatatan perlakuan akuntansi atas beban lain-lain yang terjadi namun belum dilakukan pembayaran oleh koperasi dicatat sebagai berikut:

Tabel 4.11

Koperasi Karyawan Karya Sampurna PT. Bank Mandiri Jurnal Beban Lain-lain

\begin{tabular}{|c|c|c|}
\hline Nama Akun & Debet & Kredit \\
\hline Beban Lain-lain & $\mathrm{xxx}$ & - \\
\hline Hutang Lain-lain & - & $\mathrm{xxx}$ \\
\hline
\end{tabular}

Pada Tabel 4.11, menunjukkan bahwa beban lain-lain berada pada sisi debet, sedangkan hutang lain-lain berada di sisi kredit.

Adapun pencatatan perlakuan akuntansi atas beban lain-lain ketika pihak koperasi akan melakukan pembayaran atas beban lain-lain yang ada maka koperasi akan mencatat sebagai berikut:

Tabel 4.12

Koperasi Karyawan Karya Sampurna PT. Bank Mandiri Jurnal Beban Lain-lain

\begin{tabular}{|c|c|c|}
\hline \multicolumn{1}{|c|}{ Nama Akun } & Debet & Kredit \\
\hline Hutang Lain-lain & $\mathrm{xxx}$ & - \\
\hline Kas & - & $\mathrm{xxx}$ \\
\hline
\end{tabular}

Pada Tabel 4.12, menunjukkan bahwa beban lain-lain berada pada sisi debet, sedangkan hutang lain-lain berada di sisi kredit.

Beban yang telah diakui dan dicatat ini kemudian dimasukan dalam laporan keuangan yakni laporan laba rugi. Beban ini dikurangkan pada pendapatan koperasi maka akan menghasilkan nilai sisa hasil usaha yang nantinya akan dibagikan pada anggota serta untuk pos-pos dana yang sudah ditetapkan.

Berdasarkan hasil analisis bahwa perlakuan akuntansi atas pendapatan dan beban untuk pengakuan, pengukuran dan pencatatannya sudah sesuai dengan SAK ETAP. Dan untuk penyajian dan pengungkapannya belum sesuai dengan SAK ETAP karena Koperasi Karyawan Karya Sampurna tidak membuat Catatan Atas Laporan Keuangan.

\section{KESIMPULAN DAN SARAN}

5.1 Kesimpulan

Berdasarkan hasil analisis yang telah dilakukan, dapat ditarik kesimpulan bahwa: 
1. Perlakuan akuntansi atas pendapatan pada Koperasi Karyawan Karya Sampurna PT. Bank Mandiri menggunakan metode accrual basis, dimana pengakuan pendapatan atas pinjaman uang kepada anggota dan non anggota, penjualan barang konsumsi, Bunga Bank Mandiri, cleaning service dan pendapatan lain-lain (pendapatan administrasi, pendapatan benda-benda pos, dan pendapatan jasa kebersihan) pada Koperasi Karyawan Karya Sampurna diakui menggunakan metode accrual basis.

2. Perlakuan akuntansi atas beban pada Koperasi Karyawan Karya Sampurna PT. Bank Mandiri menggunakan metode accrual basis, dimana pengakuan beban gaji, beban THR, beban honor pengurus, beban gaji cleaning service, dan beban lain-lain (Pajak $\mathrm{PPh}$ Pasal 21, asuransi, ATM/administrasi, pemakaian/perawatan alat-alat kantor koperasi, dan Bunga PNM) pada Koperasi Karyawan Karya Sampurna diakui menggunakan metode accrual basis.

3. Perlakuan akuntansi atas pendapatan dan beban pada Koperasi Karyawan Karya Sampurna PT. Bank Mandiri sudah sesuai dengan SAK ETAP dilihat dari pengakuan, pengukuran dan pencatatannya. Namun dalam penyajian dan pengungkapannya dalam laporan keuangan belum sesuai dengan SAK ETAP karena pada Koperasi Karyawan Karya Sampurna menggunakan istilah biaya sedangkan SAK ETAP menggunakan istilah beban dan Koperasi Karyawan Karya Sampurna juga tidak membuat Catatan Atas Laporan Keuangan.

\subsection{Saran} berikut:

Berdasarkan hasil penelitian yang dilakukan maka penulis memberikan saran sebagai

1. Diharapkan Koperasi Karyawan Karya Sampurna PT. Bank Mandiri selalu berpedoman pada SAK ETAP yaitu membuat laporan keuangan yang lengkap sehingga mengungkapkan kebijakan akuntansi dalam CALK agar perlakuan akuntansinya dapat berjalan dengan baik.

2. Koperasi Karyawan Karya Sampurna PT. Bank Mandiri sebaiknya dalam pencatatannya menggunakan sistem agar lebih mempermudah dan mengefektifkan pekerjaan sehingga meminimalisir kesalahan dalam pencatatan.

3. Bagi Ikatan Akuntan Indonesia sebaiknya memberikan sosialisasi terbuka mengenai penyusunan laporan keuangan dalam kaidah SAK ETAP bagi setiap yang tergolong UMKM di setiap kota yang ada di Indonesia.

\section{DAFTAR PUSTAKA}

Artaman. 2015. Analisis Faktor-Faktor yang Mempengaruhi Pendapatan Pedagang Pasar Seni Sukawati Gianyar. Skripsi. Universitas Udayana. Bali.

Ikatan Akuntan Indonesia. 2009. Standar Akuntansi Keuangan Entitas Tanpa Akuntabilitas Publik. Dewan Standar Akuntansi Keuangan. Jakarta.

Ikatan Akuntan Indonesia. 2009. 2015. Standar Akuntansi Keuangan, PSAK 1. Ikatan Akuntan Indonesia. Jakarta.

Kieso, D. E., Weygandt, J. J., dan Warfield, T. D. 2016. Akuntansi Intermediate. Erlangga. Jakarta.

Pura, Rahma. 2013. Pengantar Akuntansi 1. Erlangga. Jakarta.

Reeve, Jusuf., Warren., dan Duchar, K. 2013. Pengertian Pendapatan dan Beban Principles of Accounting. Volume 1. Salemba Empat. Jakarta.

Rini., Zulkarnain., dan Widodo. 2014. Analisis Pengakuan Pendapatan dan Beban serta Pengaruhnya Terhadap Kewajaran Penyajian Laporan Keuangan Pada PT Mitra Andalan Satkomindo. Skripsi. Universitas Bina Nusantara. Jakarta. 
Jurnal Riset Akuntansi Going Concern 13(2), 2018, 558-568

Sugiyono. 2014. Metode Penelitian Kuantitatif, Kualitatif dan R\&D. Alfabeta. Bandung. Suwardjono. 2013. Teori Akuntansi Perekayasaan Pelaporan Keuangan edisi ketiga. BPFE. Yogyakarta. 